\title{
Draft mouse genome makes public debut
}

\section{Erika Check, Washington}

A draft assembly of the mouse genome has been made public by the Mouse Genome Sequencing Consortium.

The achievement is unlikely to attract the same public attention as last year's release of the human genome - but researchers say it could be just as important to science and medicine.

"The mouse genome turns a spotlight on all sorts of features that were not apparent from the human genome," says Eric Lander, director of the Center for Genome Research at the Whitehead Institute in Cambridge, Massachusetts, one of three sequencing

centres involved in the project. "It just didn't make sense to wait until the paper came out to make sure people knew about it."

The sequence - posted on 6 May on GenBank, the main public archive of genomic information, and two other websites - covers an estimated $96 \%$ of the genome, with each base sequenced an average of seven times.

Direct comparisons between the mouse and human genomes will yield valuable information, Lander says, including the identification of regulatory regions and even new genes. But the genome will also serve as a powerful tool for biomedical researchers, who are planning to breed mice with certain

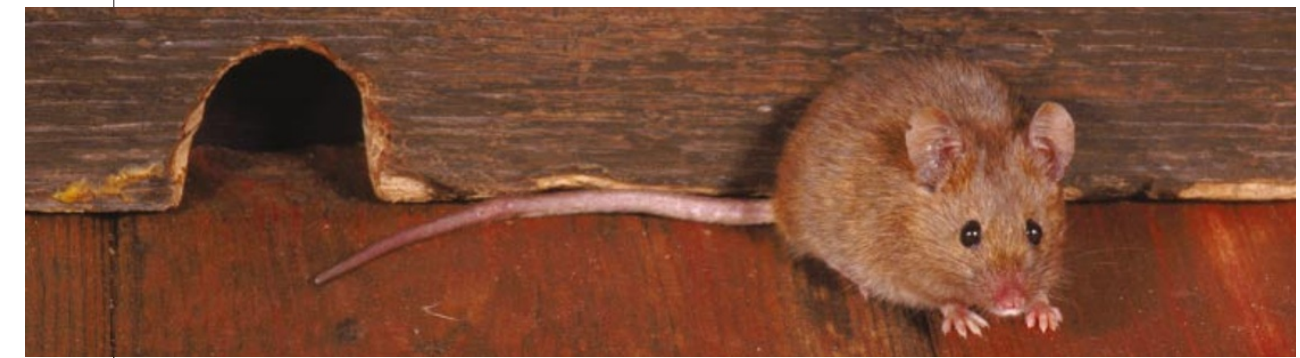

Of mice and men: comparisons between the human and mouse genomes might unearth new genes.

\section{Climate panel to focus on regions}

Jim Giles, London

Rajendra Pachauri, the new chair of the Intergovernmental Panel on Climate Change (IPCC), has pledged that under his stewardship the global advisory group will place more emphasis on regional assessments of climate change, and on its socio-economic impact.

Pachauri, the director of the Tata Energy Research Institute in New Delhi, says that the prospect of accelerated ice melting on the Himalayas is the type of regional question that the panel needs to address.

"Five hundred million people depend on these glaciers for their water supply," says the 62-year-old energy economist. "What kind of response do we have? To take an extreme example, we could move highly water-intensive industry out of that region. If you have 20 to 30 years to do that you are not going to cause major disruption."

Pachauri assumed his new position on 28 April after an unusual, contested election in which he defeated the incumbent chair, atmospheric scientist Robert Watson.

In an interview, Pachauri sought to draw a line under the election, in which many climate-change researchers expressed their support for Watson. In an article written just after the election, Al Gore, the former US presidential candidate, branded Pachauri as the "let's drag our feet candidate". Pachauri says that he had regarded Gore as a friend. "It's unfortunate that he should have played politics in this manner," he says.

Pachauri adds that the failure of the Bush administration to renominate Watson - which led to the latter being nominated late, by other nations - could be attributed to Watson's links to the previous administration of Bill Clinton. "When a new president takes over, everyone gets changed — including the janitor," he says.

The new IPCC chair says that he is now busy setting the agenda for the panel's fourth assessment report, which is due in 2007. He also wants to produce a report to give input to negotiations that begin in 2005 to set greenhouse-gas emission targets for 2013 onwards under the Kyoto Protocol. Such a report, he says, might include an assessment of technology issues, such as the potential of carbon sequestration.

Watson, meanwhile, has immersed himself in a new project. He is launching a $\$ \mathbf{5 0 0 , 0 0 0}$ feasibility study on an advisory mechanism to inform governments and international bodies on the scientific issues facing global agriculture, including the implications of genetically modified crops. genotypes and watch how they develop.

"Many laboratories have been labouring to identify mouse variants that associate with particular phenotypes," explains Francis Collins, director of the National Human Genome Research Institute in Bethesda, Maryland. "This can now be done with a few clicks of a mouse and we can move on to understanding the biology and trying to apply this to good purpose."

Collins and Lander played down the role of the public consortium's rivalry with Celera, the biotechnology company in Rockville, Maryland, in the timing of their announcement. Last April, Celera said it had assembled a draft sequence of the mouse genome that included sixfold coverage of each base, but made it available only to subscribers to its own database.

Celera is now said to be planning publication of its mouse genome in some shape or form - perhaps releasing a detailed analysis of a single chromosome. "We do have a plan to do some publishing, but we can't talk about it in any detail at this time," says Celera spokesman Robert Bennett.

www.ncbi.nlm.nih.gov

\section{Welfare amendment omits lab animals}

\section{Virginia Gewin, Washington}

In a victory for biomedical research lobbyists, rodents and birds are to remain outside the scope of the Animal Welfare Act, the main US animal-protection law.

Under an amendment to the current farm bill placed by Senator Jesse Helms (Republican, North Carolina), the US Department of Agriculture will be forbidden from extending the act to cover the animals most widely used in research. The farm bill, with the amendment intact, was approved by a conference between the House and the Senate on 26 April, and President Bush has promised to sign it after both houses vote for the agreed measure.

The act oversees the housing, healthcare and transport conditions for animals used in research. Universities and biomedical research lobbyists had campaigned energetically for its continued exclusion of mice, rats and birds.

But animal-rights groups say that the success of the amendment calls into question the relevance of the entire act, as rats and mice alone account for $95 \%$ of the animals used in laboratory research in the United States. 